International Journal of Advanced Research in Engineering and Technology (IJARET)

Volume 10, Issue 4, July-August 2019, pp. 55-62, Article ID: IJARET_10_04_007

Available online at http://iaeme.com/Home/issue/IJARET? Volume $=10 \&$ Issue $=4$

ISSN Print: 0976-6480 and ISSN Online: 0976-6499

(C) IAEME Publication

\title{
INVESTIGATING THE LOW UTILIZATION OF POZZOLANA CEMENT IN THE GHANAIAN CONSTRUCTION INDUSTRY
}

\author{
Edward Ayebeng Botchway*, Albert Masoperh \\ Kwame Nkrumah University of Science and Technology, Ghana. \\ *Corresponding Author
}

\begin{abstract}
The construction industry in Ghana has come a long way over the years with the introduction of a wide range of materials; both indigenous and imported. The Building and Road Research Institute (BRRI) conducted an extensive research on the production of Pozzolana from local resources and licensed Pozzolana Ghana Limited (PGL) as the sole producer of the cement named PozzoMix Portland Cement. One important objective was to reduce cost of cement by 18-20\%, and save up to US\$30 million annually emanating from imports. The objective of the study was to examine the reason for the low utilization and patronage of Pozzolana cement in the Ghanaian construction industry, Findings from the research indicated that the low patronage of Pozzolana cement was due to a low level of awareness, the lack of commercially available quantities of the product on the market, poor marketing and lack of active governmental support.
\end{abstract}

Key words: Pozzolana cement, patronage, construction, utilization.

Cite this Article: Edward Ayebeng Botchway, Albert Masoperh, Investigating the Low Utilization of Pozzolana Cement in the Ghanaian Construction Industry, International Journal of Advanced Research in Engineering and Technology, 10(4), 2019, pp. 55-62.

http://iaeme.com/Home/issue/IJARET?Volume=10\&Issue $=4$

\section{INTRODUCTION}

At this stage in the development of the nation Ghana, reduction in the cost of buildings has become a major concern in the drive towards infrastructural development and growth. Through the introduction of initiatives for physical infrastructural growth in the Ghanaian economy, concerns for the costs of buildings have caused professionals to look into innovative and economic means of obtaining construction projects without compromising on quality. The construction of affordable housing units all over the country to house Ghanaians and reduce congestion consequently making slums an issue of the past as well as the construction of current 
health care facilities, road networks and educational facilities has placed a lot of focus on the effective utilisation of taxpayer's contributions towards the procurement of these units. Through over 30 years of research the Building and Road Research Institute (BRRI) of the Council for Scientific and Industrial Research (CSIR), at a time when the cost of Ordinary Portland Cement (OPC) was on the rise, successfully produced Pozzolana cement from bauxite waste and clay. These clay deposits can be found in almost every district of the country [1]. Pozzolana Portland Cement (PPC) is produced from locally acquired materials and as such offers a cheaper solution to Ordinary Portland Cement (OPC). OPCs have been in the system and has come to be a trusted brand within the Ghanaian construction industry as such, it has gained a foothold in the Ghanaian market. The price of OPC is ever fluctuating and presently on the rise. The introduction of PPC into the construction industry was to complement the use of OPC and as such aid in reducing the costs of construction. This expectation for reduced construction cost has been met with the setback of extremely low patronage for the product. This document seeks to investigate into the causes for low patronage and utilisation of this innovative and highly sustainable construction material since its inception.

\section{THE MONOPOLY OF CEMENT PRODUCTION}

Cement is a highly essential construction material and represents a significant portion of construction cost. The price and availability of cement on the construction market cannot be undermined during the progress of any construction project. The production of cement is very limited and as such, there are increased concerns about limited competition within the production market. In a report to the UK Aid, it was brought to light the monopolistic concerns of Ghanaian cement producers, GHACEM. [2] In response to these allegations raised by the World Bank in 2012, concerning monopolizing Cement production in Ghana, GHACEM retorted that the monopoly was broken 12 years early on by WACEM who produced Diamond Cement in Ghana. Additionally, it was reported that other producers as well of importers of cement were in play. [3] OPC as a construction material is on very high demand within the construction industry. Continuously, the country imports high volumes of OPC all year round.

\begin{tabular}{llllll}
\hline$m$ tonnes & 2004 & 2005 & $2006 E$ & $2007 F$ & 2008F \\
Consumption & 2.45 & 2.60 & 2.70 & 2.90 & 3.05 \\
Change (56) & +4.3 & +6.1 & +3.9 & +7.4 & +5.2 \\
Production & 2.35 & 2.50 & 2.55 & 2.65 & 2.70 \\
Exports & 0 & 0 & 0 & 0 & 0 \\
Imports & 2.10 & 2.20 & 2.25 & 2.40 & 2.40 \\
\hline
\end{tabular}

Figure 1 Demand for Cement within the Country

Source [4]

The figure above gives an indication of the increasing demand for cement in the country. It is purely evident that with such high importation rates of cement, the local cement producing industries are doomed for collapse. In a bid to save the local cement producers, the government of Ghana established a committee to address the issues of high prices of imported OPC as well as seek a solution to the collapsing local producing cement industry and incidences of monopolizing Cement Production and trade within the country. [5] Following the introduction of the monitoring committee, there was the deregulation of government price within the cement 
producing industry and this allowed for more competition of Portland Cement producers into the Ghanaian market. Monopolists of OPC within the country were seen to throw a fit over the introduction of other producers within the industry. The Association of Cement Manufacturers of Ghana (CMAG) had for many years seized the control of producing and distributing bagged Portland Cement and hence the introduction of foreign producers such as African guru; Dangote Cement coming from Nigeria. This competition slashed down market prices for Cement in Ghana which posed as a good benefit for cement consumers. [6]The step of the Ghanaian government to deregulate prices of cement was highly laudable and allowed for competitive marketing of cement in Ghana.

\subsection{Alternative to Portland cement}

With the current rise in the procurement and usage of OPC, there does not seem to be an alternative to it that is capable of completely replacing this product. It is possible to supplement the OPC with other economic and sustainable options. OPC has over the years proven and been proved to be a reliable source of cementing product across construction industries. It has the advantage of early strength development which speeds up work as compared to other substitutes on the market. Additionally, it is readily available on the market and has been used in our teaching (pedagogic systems) environment for several years. In part, it is asserted that the market dominance of OPC is as a result of aggressive marketing. [7] It is only natural that after getting acquainted with a method of doing things, it would take a considerable amount of effort to switch to new products or substitutes for OPC.

Nonetheless, there are emerging trends within the construction industry and one such is the introduction of Pozzolana Portland Cement (PPC). The question remains however if there really is a substitute for OPC as we know it. PPC is an innovative cementitious construction product developed to subsidize the costs of cement in construction projects. In considering cost, environmental sustainability and long term strength, it is by far more advantageous to use PPCs over OPC. [7]

In considering the various alternatives to OPC, they are normally cheaper to produce, require far less imported technology and materials are locally acquired. Additionally, these alternatives offer social advantages by reduced cost of housing and local employment creation. Alternatives to the basic cementing property i.e. "binder" of OPC have been developed through extensive research. These are seen in the current trend of "blended cements" or pozzolanic materials utilized [7] PPCs has received positive appreciation and this is influenced by the satisfactory compressive strength resulting from the replacement of up to $30 \%$ of OPC with clay Pozzolana in Ghana. [1] Developed in Ghana by the Building and Road Research Institute (BRRI) under the Centre for Scientific and Industrial Research (CSIR), PPC (PozzoMix) is about $20 \%$ cheaper than the same sized bag for OPC. It is more workable and offers greater plasticity. [8]

\subsection{Pozzolana Additive to Cement}

Pozzolana Cements are obtained by replacing between 10 to 30 percent of OPC with Pozzolanic materials. When the percentage exceeds 30 percent, the compressive strength of the cement reduces. [9] Pozzolana is defined as any siliceous or aluminosiliceous material that, in finely divided form and in the presence of moisture, chemically reacts at ordinary temperatures with calcium hydroxide (released by the hydration of Portland cement) to form compounds possessing cementing properties [10]. Pozzolans are available in two forms. The natural Pozzolans and the artificial ones. These Pozzolans generate a pozzolanic reaction in the presence of water. They are not cementitious in nature by themselves but when ground and 
mixed with lime in cement, they improve the characteristics and strength of the concrete produced. [11] Natural Pozzolans are basically volcanic ash derived from volcanic activity. The first recorded use of volcanic ash in building construction was obtained from Mt Vesuvius located near the town of Pozzuoli giving Pozzolan its name. Other forms of Naturally occurring pozzolanic materials include;

\section{Opaline Materials}

- Opaline Shales

- Diatomaceous Earths

- Cherts

\section{Clays and Shales}

- Montmorillonite

- Kaolinite

- Illite

Natural Pozzolans demand a high degree of blending to acquire finesse and make them suitable to be used in cement. Additionally, during the calcining process, chemical additivities like alkalis can be added to improve the properties of pozzolans [12] In Ghana, where volcanic activity is absent, clay deposits become our source of natural pozzolan. These clay deposits according to surveys conducted are available in commercial quantities in almost every region of the country. [13]

\begin{tabular}{lc}
\hline Region & Tonnage(million) \\
\hline Central & 106 \\
Greater Accra & 200 \\
Eastern & 90 \\
Western & 742 \\
Ashanti & 39 \\
Brong Ahafo & 17 \\
Volta & 165 \\
Northern & 11 \\
Upper East and West & 22 \\
\hline
\end{tabular}

Figure 2 Deposits of Clay within the various regions of Ghana

Source [13]

Most natural pozzolans require grinding to a high degree of fineness to make them suitable for use in concrete and particularly with cement.

Artificial pozzolans are those that are obtained from various industrial and agricultural processes. They are usually byproducts or wastes emanating from the industrial or agricultural processes. [11] They are not well developed and require pyroprocessing before they are able to become adequately pozzolanic for use. Such examples include, fly ash, burnt clay, spent oil shales, calcined bauxite waste and suitably burnt fibrous agricultural residues such as rice husk ash. [1]. Rice is one of the most widely harvested and consumed produced agricultural product in the world and this means all such waste emanating from the processing of rice for consumption can be adequately re-used. Rice husks also referred to as paddy husks yield the largest quantity of ash and also contains the highest silica content. The high silica content in rice husk ash afford it the pozzolanic properties. [11] 


\subsection{Sustaining the Cement Industry in Ghana}

It has been already established that cement forms a vital part of any country's construction industry. As such within the Ghanaian construction industry, which experiences an influx of foreign cement products, there needs to be procedures and checks in place to properly compete with all such foreign products. PozzoMix Portland Cement in Ghana has not been widely publicized and has not received a much attention as it should. Public attention needs to be drawn to this economically viable cement complement.

GHACEM which was set up in 1967 in collaboration with NORCEM in Norway, has experienced several challenges in gaining the Ghanaian market. With the increase in cement prices over the years, GHACEM in 2004 began to utilise locally acquired limestone from the Eastern Region of Ghana to subsidize costs. After claims that there seemed to be a monopoly of cement production and sale within the Ghanaian market, government's initiative to drive prices down by deregulating prices and allowing foreign competition removed any such monopoly of the cement industry by GHACEM. Local producers of cement utilize archaic machinery in production and had unnecessarily long production lines which increased the production cost and subsequently the cost of the final product. [14] Hence when competition from foreign producers such as Dangote (Nigeria) drove down prices of cement within the nation, local producers suffered losses in an attempt to slash prices of the final cement bags to keep up with the competition. With the influx of foreign producers and importers of large quantities of bagged cement combined with the already existing local producers of cement within the country, there is an annual surplus of about 2.5 million tones and over within the country. That being said, local producers are urging government to patronize the locally produced cement for use in the housing and developmental projects springing across the nation. Additionally, government continues to urge Ghanaians to patronize "made-in-Ghana" products. [15] With reference to promoting the patronage of PozzoMix, effort needs to be put in placing the product at par with other cements already existing on the market. Advertisements and nationwide awareness need to be created for the PozzoMix to incline consumers within the industry in purchasing the product.

Presently, the production plants that were set up for the production of PozzoMix, faced eminent collapse and had to lay down about half of their workforce. This comes barely four months after the commencement of production and set-up of the factory in the Central Region. This was as a result of seriously low patronage of the product. In a bid to save the factory and prevent the complete collapse of the PPC market in Ghana.

Pozzolana Ghana Limited (PGL) instituted mechanisms to "revamp" the cement industry. [16]

\section{MATERIALS AND METHODS}

The research established the real issues causing the low patronage of Pozzolana cement in the country. The survey approach was employed in conducting the research. Data for the study was gathered from both primary and secondary sources. A properly structured questionnaire combing both open ended and closed ended questions were self-administered to solicit views for chosen respondents. Through the purposive sampling technique, a total of 100 professionals comprising Architect, Quantity Surveyors, Contractors, etc. were chosen for the study. The target area for the study was Kumasi. Kumasi is the second largest city in the country and has a population of about 1,730,249 representing 36.2 percent of the Ashanti Region. [17] Kumasi consists of adequate urban facilities and projects to warrant the use and availability or modern forms of construction within the country. New and innovative technology for use within the construction industry can be located within the Metropolis. There are large construction firms 
and consultancy firms as well as large developmental projects within the metropolis. This affords the research the viable ground for soliciting view regarding the patronage of the PPC.

Interviews were conducted to sample views on reasons for the low utilization of Pozzolana cement by stakeholders in the construction industry. These stakeholders included Architects, Contractors (Project managers and construction companies), Construction workers. The sample size for the interview is shown in Table 1.

Table 1 Respondent in Construction Industry

\begin{tabular}{|l|c|}
\hline \multicolumn{1}{|c|}{ Profession } & Frequency \\
\hline Architect & 15 \\
\hline Quantity Surveyor & 15 \\
\hline Clerk of Works & 15 \\
\hline Site Engineer & 20 \\
\hline $\begin{array}{l}\text { Cement } \\
\text { Distributor/Supplier }\end{array}$ & 25 \\
\hline Contractors & 10 \\
\hline Total & 100 \\
\hline
\end{tabular}

\section{FINDINGS AND DISCUSSIONS}

\subsection{Awareness of Presence of Pozzolana Cement}

From the interviews conducted to assess the level of awareness of professionals on pozzolana out cement, it was realized that out of the total 100 respondents chosen for the study, only 60 of them had heard about the product. With the 60 who were aware of the existence of this product, their knowledge about the product was limited. This posed as a constraint for the interview conducted because they had to be given a brief on the product before they could answer certain questions.

This lead to the discovery that most professionals were aware of the product not from advertisements or seen on shelves but they had a certain amount of classroom knowledge on the product. They also disclosed the product was introduced during training and development sessions but was not subsequently in use.

\subsection{Availability of Pozzolana Cement}

The next section of the structured questionnaire dealt with the availability of the product on the market. Respondents at this point were asked to indicate how readily available this highly sustainable product was on the market. 15 respondents out of the lot indicated that they had seen the product on shelves. This indicated the degree to which the product is made readily available on the market for consumers. For the few respondents that had an idea on the availability of the product on the market, they indicated that for bulk purchase to be made, a direct order needs to be placed at the factory. This difficulty in obtaining the product drove such consumers to use the readily available products instead. They indicated that the OPC's on the market were trusted and known brands and as such they would easily obtain the OPCs as compared to the PPC for use. All such blame cannot be pushed to the producers solely. The operate on the push market where consumers demand drive increased level of production and supply. Hence, if consumers are not demanding the product, it would not be a viable option to produce in large quantities only to have them expire on the shelves. 


\subsection{Government Policy on Pozzolana Cement}

Data gathered from secondary sources suggested that although the government gave its approval for the production of the product, there has not been a deliberate policy to promote the use of Pozzolana Cement in the construction industry. A brief interview with some staff at BRRI revealed that the government seemed to have just made promises but does not seem to want to follow through. This had been worsened by the constant change in political powers and had driven the agenda for propagating and supporting the patronage of the product down. The lack of rigorous and zealous government support does not give consumers confidence in purchasing the product. After all, if the government would not utilise them on their projects, why should others do so?

Assurances were made to use the product in most government projects such as the STX housing project, construction of schools and roads among others, it never materialized. Just a handful of projects within the country has utilised the PPC.

Aboadze Thermal Plant Fencing, ECG Ayigya District Office, Kentinkrono and Anglican SHS Dormitory block are some projects recorded to have utilized the PPC. [8]

\section{CONCLUSION}

The findings above aid us in concluding that the issues attributed to the low patronage of PPC include the low level of awareness, poor and improper marketing strategies to promote the product, unavailability of the product on the market and the lack of government policies and support to make the product a more trustworthy brand for purchase. It is simply not enough that the product is manufactured and endorsed to be highly sustainable and economically viable. Further steps to enable consumers opt for this product need to be put in place. It is important to bear in mind that this product comes at a time when there is an influx of cement producers and importers within the country. The product needs to be propagated and awareness created nationwide on the various advantages it offers over the existing ones. When consumers need to purchase PPC, it becomes worrisome to have to go all the way to place orders at the factory. This being the case, deposit points all over the country where the product can be properly stored and easily assessed can be constructed. It affords ease of patronage and reduces the transportation costs and time for the product. With talks to "revamp" PGL, more action must be seen and not just the mere promises made. Governmental policies to compel local contractors and professionals within the industry utilise PPC on project can be put in place to increase the patronage of the product thereby gradually creating mass awareness for the product.

\section{REFERENCES}

[1] J. Sarfo- Ansah, "Enhancing the Reactivity of Clay Pozzolana through Mechanical Activation, M. Phil. Thesis," Kwame Nkrumah University of Science and Technology (KNUST), Kumasi, 2010.

[2] K. Ellis and R. Singh, "Assessing the Economic Impact of Competition," Overseas Development Institute, 2010.

[3] Daily Graphic, "GHACEM Tells World Bank No Monopoly/ Duopoly in Ghana," Ghana Business News, 28 June 2012.

[4] K Sampath Kumar, U M Praveen, A Prathyusha, V Akhila, P Sasidhar, A Comprehensive Study On Partial Replacement of Cement with Sugarcane Bagasse Ash, Rice Husk Ash \& Stone Dust, International Journal of Civil Engineering and Technology, 7(3), 2016, pp. $163-172$. 
[5] International Cement Review, "The Global Cement Report 12th Ed.," Tradeship Publications Ltd, 2017.

[6] M. F. Agbernoto, "Portland Cement Monitoring Committee Inaugrated," Government of Ghana, 14 August 2016

[7] N. Sai Kiran, V. Ranga Rao, A. Venkateswara Rao and M. Achyutha Kumar Reddy, A Novel Approach for Seismic Analysis of Residential Reinforced Cement Concrete Structure and to Show It's P- Delta Effect, International Journal of Civil Engineering and Technology, 9(6), 2018, pp. 117-126.

[8] Ghana Web, "Cement War Has Helped Shatter Monopoly," Ghana Web, 19 October 2016. [Online]. Available: https://www.ghanaweb.com/GhanaHomePage/business/Cem ent-warhas-helped-shatter-monopoly-478766. [Accessed 10 April 2018].

[9] Building Advisory Service and Information Network, BASIN, "Alternatives to Portland Cement; an Introduction," Practical Action; Technical Brief, 1993. [Online]. Available: http://www.practicalaction.org. [Accessed 10 April 2018].

[10] CSIR- BRRI, Ghana, "Pozzolana Cement- FLyer," CSIR-BRRI, [Online]. Available: https://www.brri.org/pcl/Pozzolana_flyer.pdf. [Accessed 10 April 2018].

[11] The Construction Civil; the Ultimate Portal, "Portland Pozzolana Cement (PPC)," The Construction Civil; the Ultimate Construction Portal, 2017. [Online]. Available: https://www.theconstructioncivil.org/portland-pozzolanacement-ppc/. [Accessed 10 April 2018].

[12] R. Snellings, "Supplementary Cementitious Materials," [Online]. Available: https://lmc.epfl.ch/files/content/users/184559/files/L2_SCM_properties_RS.pdf. [Accessed 10 April 2018].

[13] R. Stulz and K. Mukerji, Appropriate Building Materials: A Catalogue of Potential Solutions, 3rd Edition, SKAT, IT Publications (Great Britain) \& GATE (Federal Republic of Germany), 1993.

[14] Building Materials, "Pozzolana and Pozzolanic Properties," Gharpedia, 2018. [Online]. Available: https://gharpedia.com/pozzolana-and-pozzolanic-properties/. [Accessed 12 April 2018].

[15] M. Bediako, "Thermally Activated Clay and Biomass Mixtures as Cementitious Materials for Sustainable Construction in Ghana, PhD Thesis," Kwame Nkrumah University of Science and Technology (KNUST), Kumasi, 2015.

[16] E. A. Mensah, "Optimum Production Problem: A Case Study of GHACEM- Takoradi, B. Ed," Kwame Nkrumah University of Science and Technology, Kumasi-Ghana, 2011.

[17] M. Kwofi, "New Policy to Regulate Cement Industry," Graphic Online, 17 May 2016. [Online]. Available: https://www.graphic.com.gh/business/business-news/newpolicy-toregulate-cement-industry.html. [Accessed 12 April 2018].

[18] Ghana Business News, "Pozzolana Ghana Takes Giant Step to Revamp Cement Industry," Ghana Business News, 22 April 2012.

[19] Kumasi Metropolitan Assembly, "Metropolitan Census Report for Kumasi Disseminated," Kumasi Metropolitan Assembly, 15 February 2015. [Online]. Available: $\mathrm{http} / / / \mathrm{kma} . g o v . \mathrm{gh} / \mathrm{kma} /$ ?metropolitan-census-report-forkumasi-disseminated\&page $=5484$. [Accessed 13 April 2018]. 